\title{
Introduction from the Guest Editors
}

\section{Knowledge Spheres: \\ Borderlines and Intersections of Expertise and Knowing in China, Song to Qing}

\section{Dagmar Schäfer}

[Dagmar Schäfer is a specialist in the history of science and technology in China (Song to Ming). Director of the Max Planck Institute for the History of Science (MPIWG), Dep. III, Artefacts, Action and Knowledge, and Professor at the Centre for Chinese Studies at the University of Manchester, United Kingdom, she received her Ph.D. from the University of Würzburg, Germany in 1996. She has worked and studied at the Zhejiang University PR China, the Ts'inghua University ROC, the University of Pennsylvania, U.S.A. and the Max-PlanckInstitute for the History of Science, Berlin, Germany. Her publications include The Crafting of the 10,000 Things (University of Chicago Press, 2011), for which she received the renowned Pfizer Award of the History of Science in 2012 and the Joseph Levenson Book Prize (pre-1900 category) of the Association for Asian Studies in 2013. Contact: dschaefer@mpiwg-berlin.mpg.de]

\section{Sun Xiaochun}

[Sun Xiaochun is Professor of the History of Science at the Institute for the History of Natural Science (IHNS), Chinese Academy of Sciences (CAS). He received his Masters degree in Astronomy from Nanjing University in 1989 and his Ph.D. in History of Astronomy from the Chinese Academy of Sciences in 1993. He also studied the history and sociology of science at the University of Pennsylvania and received his second Ph.D. in 2007. He has published primarily on the history of Chinese astronomy and co-authored The Chinese Sky during the Han (Leiden: Brill, 1997). His current research interests are history of astronomy and science and society in Song China. Contact: xcsun@ihns.ac.cn]

$$
* * *
$$

This special issue (Nr 38 and 39 of EASTM) originates from a cooperation between the MPIWG Germany, and the IHNS, Beijing (Sep. 2007-Aug. 2012). Over the course of three years, members of the Independent Research Group Concepts and Modalities of Practical Knowledge Transmission 
and the Max Planck Society (MPG) and CAS ${ }^{1}$ partner group cooperated on the project: Borderlines and Intersections of Knowledge Spheres in Pre-Modern China, 10 th to $18^{\text {th }}$ Century. First drafts of the papers at hand were presented at the eponymous workshop held in Beijing 24-27 April 2010. ${ }^{2}$

The main concerns of our project were twofold: to analyse the methods of constructing expertise beyond the historical categories of 'institutions', 'professions' and 'disciplines'; and to show how actors, while handling specific tasks, concerns, or activities, manifested fields of knowledge through social and ritual means, writing, and the visual or spatial manipulation of artefacts, people and landscapes. These special issues, 38 and 39 of EASTM, feature selected cases from the tenth to the eighteenth centuries: astronomical position-holding during the Northern Song era (960-1126) (Han Yi; Sun Xiaochun), the Daoist Wu Wu's 呉悞 (active during Southern Song 1127-1279) ways of transmitting the dao 道 of elixirs (He Juan), the changing role of zhuyou 祝由 practices in healing and ritual imagination from the Song to the early Qing (1645-1912) eras (Philip Cho), pre-and post-1126 siege defence and the commemoration of Kaifeng's urban space (Ari Levine), and the transformation of temple space in the city of Yuncheng, famous for its salt production during the 1650s (Andreas Janousch).

Interested in the combined use of formal and informal means, the project worked with Willard V. O. Quine's (1908-2000) notion of "spheres of knowledge". ${ }^{3}$ Quine identified knowledge as the methods and means by which actors link data and information, observational statements and empirical evidence to a core concern. This definition draws attention to the actor's crucial choices and strategies of gathering, documenting and communicating information, and, at the same time, acknowledges the

${ }^{1}$ The MPG and CAS began their cooperation in 1974. The partner group program was inaugurated in 1999.

${ }^{2}$ Several members of the evaluation board were present at the workshop too. We would like to thank all evaluation board members for their continuous support and most useful advice: Professors Fu Daiwei (National Yang-Ming University, Taiwan), Francesca Bray (University of Edinburgh, UK), Jürgen Renn (MPIWG/MPG), and Liao Yuchun (IHNS, CAS), Zhang Baichun (IHNS, CAS).

${ }^{3}$ While the expression is now widely used, Quine is one of the few who defines it. His discussion rests on references rather than names or meanings, and avoids a discussion of the relation between reality and words. Quine's approach stands in contrast to the Kantian distinction of three spheres of knowledge (science, morality and aesthetics) based on types of reasoning. See W. V. Quine (1951), "Two Dogmas of Empiricism", The Philosophical Review, Vol. 60, No. 1. pp. 20-43. See also Willard V. Quine (1960), Word and Object (Cambridge MA: Massachusetts Institute of Technology [2013 reprint]), p. xxv. 
fragmentary nature of written accounts and artefacts when identifying historical knowledge regimes.

Beginning with the Song era (960-1279), our project conceded to a historiography that correlates qualitative and quantitative shifts in approaches to knowledge and expertise with socio-political change and the upsurge of print. The increased importance of paper for information flow and knowledge production is indeed the product of a long historiography. Song contemporaries such as Li Tao 李濤 (1115-1184) nurtured such views when he purposefully depicted Zhao Kuangyin 趙匡胤 (927-976, reigned from 960), founder of the Song Dynasty (960-1279) as a man of vast reading: "he purchased every curious book that he heard of, even if it cost him a thousand pieces of gold" (聞人間有奇書, 不文千金購之). This conclusion is drawn in relation to an anecdote in which the general and emperor of the Later Zhou Shizong 周世宗 (921-959) once asked: “what is the use of books when military forces are essential for expanding territory?" (開封疆, 當務 監甲利兵, 何用書為). To which Kuangyin replied: “having no clever strategy to strengthen imperial virtues, I humbly hold my position just to make up the numbers, fully aware of my incompetence. I collect books for the purpose of broadening my views (i.e. what can be seen and heard) and increasing my wisdom." (臣無奇謨上贊聖德, 濫膺寄任, 常恐不逮, 所以聚 書, 欲廣聞見, 增智虑也). ${ }^{4}$ Here is an emperor who took refuge in books to compensate for a deficiency in human advice.

Indeed, the history of science owes many of its sources to the Song rulers' preoccupation with the written word as the state nurtured a growing paper bureaucracy. A prime example is Su Song's 蘇頌 (1020-1101) renowned tract Xin yixiang fayao 新儀象法要 [Essentials of the Method for the New Instrument], which was compiled as a funding request and then filed as evidence of the project's success. ${ }^{5}$ Such examples demonstrate that the new dynastic rulers and the newly emerging class of elite scholarliterati worked hand in hand. Both attempted to harness society and stateand certainly each other - with bonds of paper and ink.

While bookish learning would, as Joseph P. McDermott and many others have noted, indeed become central to the identity and legitimacy of China's cultural and political elite over the subsequent millennium, ${ }^{6}$ this

${ }^{4}$ Li Tao 李濤 (1115-1184) (1985), Xu zizhi tongjian changbian 續資治通鑑長編 (Topical Narrative of the Long Draft of the Continued Comprehensive Mirror for Aid of Governance) (Shanghai: Guji chuban she), ch. 7, 645 (6-a-b).

${ }^{5}$ For a recently revised edition, see Su Song, Lu Jingyan 陸敬嚴 (ed.) (2007), Xin yixiang fayao 新儀象法要譯注 (Translation and Annotation of the Essentials of the Method for the New Instrument) (Shanghai: Shanghai guji chuban she).

${ }^{6}$ Joseph P. McDermott (2006), A Social History of the Chinese Book (Hong Kong: Hong Kong University Press), p. 4; Frederick W. Mote (1999), Imperial China, 9001800 (Cambridge MA: Harvard University Press), p. 346. 
move did not mean the absolute triumph of texts in the transmission of knowledge and know-how. Rather it created what Hilde de Weerdt has recently termed a new 'information order' ${ }^{7}$ On the one hand the new dynastic rulers sponsored the printing of classics, materia medica, historiographic, administrative and encyclopaedic texts. On the other hand, these rulers also carefully regulated what went into print, and consciously exploited and refined means of communication to implement new policies, knowledge and ideas. The rise of paper and print hence caused modes of transmission to become means of expression for different kinds of expertise.

The contribution of Sun Xiaochun and Han Yi to this theme probes the boundaries of the institutional category in the context of court astronomical endeavours. Sun and Han carefully frame astronomy and calendar-making as a political activity that aimed at advising the emperor and organizing society. They show how the state maintained expertise for over two hundred years by investing in people and instruments. Within 150 years approximately 100 officials served at the astronomical bureau. Fixed salaries and variable subsidies were granted to the various officers attached to the Bureau of Astronomy, according to their administrative ranks and functions. Money, and with it a constant supply of manpower led to increased expertise. Sun and Han's analysis also divulges that the state pursued instrument building, and thus the representational materiality of the trade as an extra-curricular effort.

Cho tests the boundaries of expertise within statecraft by following a moving target: namely, how zhuyou 祝由 objects, ideals and practices were used in state healing practices and ritual discourse. Cho shows how zhuyou moved through different social settings from the Imperial Academy to temples and homes, and emphasizes the dynamic character of zhuyou expertise that enabled various actors - patients, healers, their families and friends-to follow quite varied, and, to the historian, sometimes contradictory meanings and modes of efficacy. This variable approach to expertise brings to mind Robert Campany's notion of religious groupings as dynamically 'imagined' communalities and repertoires of resources: "A repertoire may contain different and indeed contradictory models of certain areas or aspects of life because these models answer different sets of questions; people resort to these models in their discourse about meanings and values even when they reject certain implications of each model as implausible, in part because each model describes something about the real constraints of life and institutions or, rather (more correctly), about the

${ }^{7}$ Hilde de Weerdt (2006), "Byways in the Imperial Chinese Information Order: The Dissemination and Commercial Publication of State Documents", Harvard Journal of Asiatic Studies 66 (1), pp. 145-188. 
lines of action individuals pursue in the context of those constraints and institutions." ${ }^{8}$

Cho emphasizes not only the reciprocity of experts and non-experts but also individuals and the state (or other communal efforts) in the creation and identification of expertise. That individual strategies reacted to and informed state strategies of knowledge and information flow is also evident in Daoist Wu Wu's approach to textual transmission, as He Juan's analysis shows. Wu's approval of written transmission is in contrast to earlier Daoist approaches, in which the authority of texts mainly derived from the fact that the master directly transmits the texts to his disciple. ${ }^{9}$ Both $\mathrm{Wu} W \mathrm{Wu}^{\prime} \mathrm{s}$ approval and the Daoist stance stand in relation to shifting dynastic information politics, subtle changes of which are still open to debate.

$\mathrm{Wu}$ Wu's case emphasizes a point when Chinese actors debated texts in contrast to the benefits of oral transmission. For some, the text challenged personal tutelage, for others texts could only work as a complementary tool. Clearly, Daoists did not all believe in the superiority of texts, and some emphasized that the mutual recognition of teacher and disciple was key to understanding. Personal engagement addressed that which could not be transmitted by the textual record. He Juan also suggests that whereas before the third century Daoists were concerned with whether a teacher could "teach" true knowledge, Wu emphasized that true knowledge and its actual implementation was an issue of personal capacity.

In contrast to many of his colleagues, He Juan suggests, Wu Wu insisted that the supremacy of the teacher was not broken by a textual transmission per se: a text conveyed information that would in any case only be useful to an initiate who was able to decipher and transform the information of the text into knowledge. This notion probably most closely coincides with Quine's idea of the knowledge sphere, in that the text is highlighted primarily in its function as a source of information.

$\mathrm{Wu} \mathrm{Wu}$ stands at the beginning of a fervent debate around printed materials in Daoist thought. A later master named Shi Zhijing 史志經 (c. 1202-?) suggested that printing was "far more effective in transmitting

${ }^{8}$ Robert F. Campany (2003), "On the Very Idea of Religions (In the Modern West and in Early Medieval China)", History of Religions 42 (4), pp. 287-319, 318; see also Robert F. Campany (2012), "Religious Repertoires and Contestation: A Case Study Based on Buddhist Miracle Tales", History of Religions 52 (2), pp. 99-141, 106. Campany's approach is an extension of Ann Swidler's notion of cultural repertoires, see Swidler (1986), "Culture in Action: Symbols and Strategies", American Sociological Review 51 (2), pp. 273-286.

${ }^{9}$ Mark Csikszentmihalyi (2002), “Traditional Taxonomies and Revealed Texts in the Han", in Livia Kohn \& Harold D. Roth (eds.), Daoist Identity: History, Lineage, and Ritual (Honolulu: University of Hawai'i Press), pp. 81-148, 94. 
Daoist life and acts (Dao heng 道行) than having them engraved on bronze or jade", arguing that both carriers of such writing could also both be destroyed. ${ }^{10}$ Shi's remark reveals another impact of the upsurge of paper and print: namely that the facilitated reproducibility of texts had provoked discussions about the relation between the materiality of textual knowledge exchange and the originality and validity of written information. Scholars hence began to look for ways to verify what was transmitted in texts, and found other sources to substantiate or defy the orthodox canon of thought - preferably inscriptions on bronzes, artefacts or stones. This caused literati to engage into the field of epigraphy (jin shi xue 金石學), which emerged hand in hand with the collection and connoisseurship of antique bronzes, stele or other artefacts.

Later catalogues such as Wang Chang's 王昶 (1725-1806) Jinshi cuibian 金石翠編 (Collection of Fine Metal and Stone Inscriptions) in 160 juan 卷 illustrate the Song's 'epigraphic habit'11 within a historical context. Wang lists about eleven hundred bronze and stone inscriptions from the Zhou through the Jin dynasty in the thirteenth century, including records ( $j i$ 記) inscriptions (ming 銘), eulogies (song 頌), commemorative inscriptions (bei 碑) and poetry (shi 詩), to commemorate religious, social and political activities. Other steles served as military and territorial emblems or as public announcements. Text was painted, chiselled and carved on rocks in the landscape, as upright steles or deliverable tablet formats. ${ }^{12}$

Research has amply shown that such catalogues of stele rubbings mobilized the locally situated texts - words carved in stone-across time and space. Andreas Janousch's study brings into view another important facet of how actors mobilized such seemingly immobile texts when he reminds us that even where they were located such steles created changing landscapes of information and ideas. He shows how actors, such as the salt commissioner Zhao Rujin 趙如瑾 (fl. 1649-1655), mobilized meanings through topical re-arrangements of the steles at the temple site to enhance a message's credibility or to address novel concerns. The 'epigraphic habit' in Ming China hence fully exploited the conceptual and spatial capacity of knowledge flow.

${ }^{10}$ Lucille Jia (2011), “The Uses of Print in Early Quanzhen Daoist Texts," in Hilde de Weerdt \& Lucille Jia (eds.) (2011), Knowledge and Text Production in an Age of Print: China 900-1400 (Leiden: Brill), pp. 167-214, 194.

${ }^{11}$ Ramsay MacMullen (1982), "The Epigraphic Habit in the Roman Empire", American Journal of Philology 103, pp. 233-246, 234.

${ }^{12}$ For Wang's catalogue see, for instance, the edition of the Lidai beizhi congshu 歷 代碑誌叢書 (Collectanea of Stele Inscriptions from Various Ages) (Nanjing: Jiangsu guji chubanshe, 1998). See also Dorothy Wong (2004), Chinese Steles: Pre-Buddhist and Buddhist Use of a Symbolic Form (Honolulu: The University of Hawai'i Press), pp. 4, 34 . 
Janousch's study highlights the dynamic character of spatial arrangements, and reminds us that, from a historical perspective, continuity cannot be taken for granted. In this sense landscapes are the most difficult sources of information for historians as their changes are not easily traceable. Conversely, as P. J. Ethington suggests, "Histories representing the past represent the places (topoi) of human action. Knowledge of the past, therefore, is literally cartographic: a mapping of the places of history indexed to the coordinates of spacetime." ${ }^{13}$ In discourse on Song China and the locale we might modify Ethington's cartographic to "chorographic",-a term that Ptolemy used to distinguish the study of smaller parts of the world, such as provinces, regions, cities, or ports, from that of how these smaller parts form a geography, that is, the study of the whole world. Chorography "takes note of all particularities and properties, as small as they may be (...)."14

Chorography, devoted to place, also emphasizes the quality of place, and that the sense of the local and of belonging is intrinsic to the construction of space. It makes a distinction between place-finding, placetaking, and place-making. This also includes that space is defined by inhabited spots and not by the gaps between these spots (in this regard the dots we put on maps are quite fitting). Connected terms in modern leaning are deep mapping and temporal topographies, which serve as ways to grasp Levine's reconstruction of a multifaceted image of Kaifeng from the Southern Song ambassadors' nostalgia-tinged descriptions of Jurchenoccupied Kaifeng.

Text and landscape worked together, as Christian de Pee also has observed in his study of Luoyang: "archaeological traces, moreover, reveal an alternative textual geography, preserved underground, commemorating the names of craftsmen and soldiers in bricks and tiles, and in unadorned tombstones." ${ }^{15}$ The institutional topography was laid out in steles and funeral stones, while "inscriptions composed for locations outside the city walls likewise draw details from their setting into the text, to substantiate and control the meaning of the landscape." ${ }^{16}$

The authors' analyses of historical information strategies in this special issue takes into consideration that their actors may not have assumed that true understanding was only situated in texts. Changing institutional set-

${ }^{13}$ P. J. Ethington (2007), "Placing the Past: Groundwork for a Spatial Theory of History", Rethinking History 11 (4), pp. 465-93, 466.

${ }^{14}$ Ptolemy (second century), Geographica. See also Peter Apianus, Cosmographia (Antwerp 1540)

${ }^{15}$ Christian de Pee (2009), "Wards of Words: Textual Geographies and Urban Space in Song Dynasty Luoyang, 960-1127", Journal of the Economic and Social History of the Orient 52, pp. 85-116, 92

16 ibid., 98 
ups of dynasties to recruit personnel in fields such as astronomy, the various ways in which zhuyou practices and objects moved through and were referenced in fields of health care or ritual debates, $\mathrm{Wu} \mathrm{Wu}^{\prime}$ s notion of the usefulness of texts, the censor's versatile mobilization of stele texts and Song actors' enactment with landscape and space exemplify comprehensive approaches to knowledge circulation, in practice and in theory, and show that spheres of knowledge were flexibly defined both spatially and materially. These contributions suggest that within the varying emphases individuals and communities give to the movement of people and materials lies another important key to unlock the shifting values that state, society and individual assigned to practice, theory, action and thought at any given time. Historical research holds that the combination of such means depended on what actors thought knowledge was and how it should be made. Research in this issue suggests that in a culture that gives substantial emphasis to the enactment of understanding, the combined methods of circulating information, or strategies of communicating data must also be taken into account. 